\title{
Problematika Pembelajaran Membaca Al-Qur'an Di Madrasah Tsanawiyah Negeri Ujung Gurap Padangsidimpuan
}

\author{
Fitriani $^{1}$ \\ Email: fitriani@um-tapsel.ac.id
}

\begin{abstract}
This research was conducted using descriptive qualitative methods with a sample of 4 BQ teachers from 8 existing BQ teachers and 33 students (grade VII). Then this research was carried out by collecting interview and observation data while the technique guarantees the validity of the data in this study was to use triangulation. The results of this study have found a change in the attitudes and nature of the students in learning to read the Qur'an at MTs N Ujung Gurap even though the results achieved have not been maximized. This is in accordance with the answers to the interviews with BQ teachers and VII grade students of MTs N Ujung Gurap, namely the implementation of learning to read the Qur'an including planning, implementation, and evaluation. While the obstacles encountered include the lack of student fees, the facilities are still minimal and the allocation of time is lacking, the solution is to provide motivation, utilize existing facilities and make available time efficient.
\end{abstract}

\section{Keywords: Learning problems; Reciting Al-Qur'an}

\begin{abstract}
Abstrak
Penelitian ini dilaksanakan dengan menggunakan metode kualitatif deskriptif dengan sampel penelitian sebanyak 4 guru BQ dari 8 guru BQ yang ada dan 33 siswa-siswi (kelas VII). Kemudian penelitian ini dilaksanakan dengan pengumpulan data wawancara dan observasi sedangkan tekhnik menjamin keabsahan data dalam penelitian ini ialah dengan menggunakan triangulasi. Hasil penelitian ini telah menemukan adanya perubahan sikap dan sifat para siswa-siswi dalam pembelajaran Membaca Al-qur'an di MTs N Ujung Gurap sekalipun hasilnya yang dicapai belum maksimal. Hal ini sesuai dengan jawaban wawancara dengan guru-guru BQ dan siswa-siswi kelas VII MTs N Ujung Gurap yaitu pelaksanaan pembelajaran Membaca Al-qur'an meliputi perencanaan, pelaksanaan, dan evaluasi. Sedangkan kendala-kendala yang ditemui meliputi kurangnya minay siswa-siswi, fasilitas yang masih minim dan alokasi waktu yang kurang, solusi yang dilakukan adalah dengan memberi motivasi, memanfaatkan fasilitas yang ada dan mengefisienkan waktu yang ada.
\end{abstract}

Kata kunci: Problematika pembelajaran; Membaca Al qur'an

\footnotetext{
${ }^{1}$ Dosen Universitas Muhammadiyah Tapanuli Selatan
} 


\section{A. PENDAhuluan}

Belajar mengajar pada dasarnya merupakan proses interaksi edukatif antara guru dan siswa. Tujuan dari interaksi edukatif tersebut meliputi tiga aspek, yakni aspek kognitif, afektif dan psikomotorik. Untuk mencapai tujuan secara baik, diperlukan peran maksimal dari seorang guru, baik dalam penyampain materi, penggunaan metode, pengelolaan kelas dan sebagainya.

Problem adalah suatau masalah yang dihadapinya serta sesuatu hal yang sedang dia lakukan dengan tujuan yang ingin dicapainya. Dengan kata lain kegiatan adalah suatu langkah-langkah untuk mencapai suatu tujuan yang diharapkan agar tujuan yang dilakukan itu bisa diselesaikan dan bisa di himpun menjadi sebuah keberhasilan. Sedangkan di sini peneliti hanya membahas problematika pembelajaran BQ. Untuk melihat masalah yang dihadapi siswa dalam membaca dan menulis qur'an. Sedangkan Al-qur'an adalah mukjizat Nabi yang abadi. Kemajuan ilmu itu tidak akan bertambah kecuali meresapkannya dengan jiwa. Al-qur'an ini adalah tidak ada taranya diturunkan kepada rasul untuk mengeluarkan umat manusia dari alam kegelapan ke alam yang terang benderang, serta menunjukkan ke jalan yang lurus.

Pengajian Al-qur'an (PAI) adalah usaha sadar untuk menyiapkan siswa dalam meyakini, memahami, menghayati dan mengamalkan agama islam melalui kegiatan bimbingan, pengajaran, latihan dengan memperhatikan tuntunan untuk menghormati agama lain dalam kerukunan antar umat beragama.

Mempelajari Al-qur'an isi dan kandungannya harus di dahului dengan membaca. Perintah membaca ini sendiri merupakan wahyu pertama yang telah di terima oleh rasul yang disampaikan melalui malaikat jibril. Karena dengan membacalah Allah mengajari manusia tentang pengetahuan yang belum dia ketahui, hal ini sesuai dengan firman Allah :

"bacalah dengan (menyebut) nama Tuhanmu yang Menciptakan, Dia telah menciptakan manusia dari segumpal darah, Bacalah, dan Tuhanmulah yang Mahapemurah, yang mengajar (manusia) dengan perantaran kalam, Dia mengajar kepada manusia apa yang tidak diketahuinya".

Dalam membaca Al-qur'an yang menjadi objek bacaan adalah ayat-ayat Al-qur'an, oleh sebab itu membaca merupakan awal yang baik mempelajari dan memahami isi kandungan Al-qur'an. Membaca ayat suci Al-qur'an merupakan pekerjaan yang utama, yang 
memunyai keistimewaan dan kelebihan dibandingkan dengan membaca bacaan yang lain. Sesuai dengan arti Al-qur'an diturunkan memang untuk dibaca.

Al-qur'an sebagai pedoman hidup ummat manusia di tulis dengan bahasa arab, berguna bagi mannusia dalam memudahkan membaca serta memahaminya tentu memiliki peraturan-peraturan dalam membacanya. Firman Allah di dalam Al-qur'an sebagai berikut :

"Sesungguhnya Kami menurunkannya berupa Al Quran dengan berbahasa Arab, agar kamu memahaminya". 2

Dari paparan singkat diatas bahwa kegiatan membaca Al-quran merupakan kegiatan yang dapat menunjangkegiatan belajar siswa, termasuk kegiatan yang dapat menunjang aktivitas belajar siswa dikelas.

Permasalahan ini banyak terjadi di kalangan masyarakat, misalnya peserta didik yang sedang mengikuti pengajian al-qur'an di dalam sekolah maupun diluar sekolah masih minim pengetahuan tentang baca tulis qur'an, yang disebabkan kegiatan yang dilakukan tidak secara terus menerus dan tidak di dampingi dan diajar secara sistemastis.

Kegiatan pengajian al-Qur'an ini dimaksudkan untuk membawa minat peserta didik agar semakin dekat dan taat kepada allah dan kegiatan ini membuat peserta didik semakin bisa meluangkan waktu senjangnya untuk mempelajari dan memahami al-qur'an sesuai yang telah diajarkan oleh agama. Untuk membuktikan dugaan peneliti, peneliti merasa tertarik untuk menelitinya tentang permasalahan-permsalahan yang terjadi pada pembelajaran alQur'an dengan judul : Problematika Pembelajaran Membaca Al-Qur'an di Madrasah Tsanawiyah Negeri Ujung Gurap Padangsidimpuan.

\section{B. METODOLOGI PENELITIAN}

Berdasarkan analisis data, penelitian ini mengunakan pendekatan kualitatif yaitu penelitian yang dilakukan dengan mengamati fenomena disekitarnya dan menganalisisnya dengan mengunakan logika ilmiah. ${ }^{3}$ Berdasarkan metode, penelitian ini didekati dengan metode deskriptif yaitu penelitian yang berusaha menggambarkan dan menginterprestasikan objek sesuai dengan apa adanya ${ }^{4}$. Pendekatan ini ditentukan berdasarkan pertimbangan

\footnotetext{
${ }^{2}$ Tim Penyusun Departemen Agama RI, Al-Qur'an dan Terjemah (Bandung: Diponorogo, 2000), hlm. 187.

${ }^{3}$ Lexy J. Moleong, Metodologi Penelitian Kualitatif, (Bandung: Rosda Karya, 2000), hlm. 5.

${ }^{4}$ Suhardi, Motodologi Penelitian Pendidikan Kompetensi dan Praktiknya, (Jakarta: PT. Bumi Aksara,
} 2003), hlm. 157. 
bahwa penelitian ini bertujuan untuk menggambarkan Problematika Pembelajaran membaca Al-Qur'an Kelas VII di MTs N Ujung Gurap Padangsidimpuan.

Jadi, penelitian ini termasuk penelitian lapangan, Berdasarkan tujuan penelitian ini termasuk penelitian eksploratis yaitu penelitian yang dilakukan bertujuan menggungkap fenomena murni ${ }^{5}$. Dalam penelitian ini penulis menggambarkan peristiwa maupun kejadian yang ada dilapangan, seperti pelaksanaan pembelajaran membaca Al-Qur'an, problem pembelajaran, upaya mengatasi problem. Penelitian ini digunakan untuk menggambarkan dan memproleh data sehubungan dengan Problematika Pembelajaran membaca Al-Qur'an Kelas VII di MTs N Ujung Gurap Padangsidimpuan.

Penelitian ini merupakan penelitian kualitatif, maka instrument pengumpulan data yang cocok adalah data yang diperoleh melalui:

1. Wawancara

Wawancara merupakan tehnik pengumpulan data yang digunakan peneliti untuk mendapatkan keterangan lisan melalui bercakap-cakap dengan orang yang dapat memberikan keterangan pada peneliti. ${ }^{6}$ Yakni dengan cara melakukan wawancara dengan siswa-siswi Kelas VII MTs N Ujung Gurap Padangsidimpuan.

2. Observasi

Observasi merupakan pengamatan dan pencatatan secara sistematis terhadap gejala yang tampak pada objek penelitian. Pengamatan dan pencatatan yang dilakukan terhadap objek ditempat terjadi atau berlangsungnya peristiwa. ${ }^{7}$ Yaitu peneliti langsung turun ke lokasi penelitian untuk mengamati masalah yang akan diteliti.

Sumber data penelitian yang bersifat kualitatif yang peneliti gunakan adalah sumber data primer.

1. Sumber Data Primer

Sumber data primer adalah sumber data yang di proleh secara langsung dari objek penelitian perorangan, kelompok, dan organisasi. ${ }^{8}$ yaitu melalui wawancara mendalam (indept interview) dan observasi partisipasi. Berkaitan dengan hal tersebut, wawancara mendalam dilakukan kepada guru-guru yang mngajar Alqur'an.

${ }^{5}$ Ibid, hlm. 7.

${ }^{6}$ Mardalis, Metode Penelitian Suatu Pendekatan Proposal, (Jakarta: Bumi Aksara, 1995), hlm. 64.

${ }^{7}$ Sukardi, Metode Pendidikan Kompetensi dan Praktiknya, (Jakarta: Bumi Aksara, 2013), hlm. 158.

${ }^{8}$ Rosady Ruslan, Metode Penelitian, (Jakarta: PT.Raja Grafindo Persada, 2003), hlm.29. 


\section{Sumber Data Skunder}

Sumber data sekunder adalah sumber dat yang diperoleh secara tidak langsung dari informan di lapangan, seperti dokumen yaitu data sekolah, data guru-guru, data siswa dan sebagainya.

Dalam analisis data ada beberapa langkah-langkah yang harus di perhatikan sipeneliti. Adapun langkah-langkah tersebut antara lain ${ }^{9}$

1. Mengorganisasi data. Dalam hal mengorganisasi data banyak sekali data terkumpul di antaranya catatan lapangan, komentar peneliti, gambar, poto, dokumen berupa laporan, dan sebagainya, maka disinilah diperlukan dengan cermat pengorganisasian data.

2. Membaca dan menelaah dengan cermat dan teliti hasil yang didapatkan dilapangan. Seluruh data, baik yang berasal dar pengamatan berperan serta, wawancara, komentar peneliti sendiri, gambar atau fhoto hendaknya dibaca dan ditelaah secara mendalam. Seluruh bagiannya merupakan potensi yang sama kuatnya dalam menghasilkan sesuatu yang dicari.

3. Memberikan tanda atau kode pada judul pembicaraan yang dianggap bisa menjadi cikal bakal tema.

4. Mengelompokkan data sesuai dengan tipologi atau kerangka klasifikasi. Kerangka klasifikasi atau tipologi akan bermanfaat dalam menemukan tema.

5. Membaca literatur yang ada kaitannya dengan masalah dan latar penelitian. Selama dan seudah pengumpulan data perpustakaan yang berkaitan dan relevan dengan masalah studi kehendaknya di pelajari. Maksudnya ialah untuk membandingkan apa yang ditemukan dari data dengan apa yang dikatakan dalam kepustakaan profesional.

Adapun teknik menjamin keabsahan data penelitian ini dilakukan dengan cara:

a. Perpanjangan keikut sertaan, yaitu peneliti terjun langsung ke lokasi guna untuk berorientasi dengan situasi dan juga mendeteksi serta memperhitungkan distori yang mungkin mengotori data. ${ }^{10}$

\footnotetext{
${ }^{9}$ Lexy J. Moleong, Op-Cit, hlm. 103-105.

${ }^{10}$ Ibid, hlm. 327.
} 
b. Ketekunan pengamatan, yaitu mencari secara konsisten interpretasi dengan berbagai cara dengan kaitannya dengan proses analisis yang konstan. ${ }^{11}$ Artinya menemukan ciri-ciri dan unsur-unsur dalam situasi yang sangat relevan dengan persoalan atau isu yang sedang dicari dan kemudian memusatkan diri pada hal-hal tersebut secara rinci.

c. Tringulasi, yaitu peneliti dapat mencek kembali temuannya dengan jalan membandingkannya dengan berbagai sumber, metode atauteoi. ${ }^{12}$

d. Pengecekan anggota, yaitu mengumpulkan para peserta yang telah ikut menjamin sumber data dan mengecek kebenaran data dan interpretasinya. ${ }^{13}$

e. Uraian rinci, yaitu dengan melaporkan hasil penelitian sehingga uraiannya itu dilakukan seteliti dan secermat mungkin yang menggambarkan konteks tempat penelitian diselenggarakan. ${ }^{14}$ Artinya laporan itu harus mengacu pada focus penelitian dan uraiannya harus mengungkapkan secara khusus sekali segala sesuatu yang dibutuhkan agar dapat memahami temuan-temuan yang diperoleh.

Dari berbagai teknik diatas, peneliti hanya memakai tehnik triangulasi dengan sumber, yaitu peneliti mencek kembali temuan yang ada dilapangan dengan jalan membandingkan data hasil wawancara dengan hasil observasi, membandingkan apa yang yang dikatakan orang didepan umum dengan apa dikatakannya secara pribadi dan membandingkan keadaan dengan berbagai pendapat dan pandangan orang seperti rakyat biasa., oang yang berpendidikan menengah atau tinggi dan orang berada. Dan pengecekan anggota, yaitu bergaul dengan para subjeknya dan melakukan wawancara, serta uraian rinci yaitu, melaporkan hasil penelitian sehingga uraiannya itu dilakukan seteliti dan secermat mungkin yang menggambarkan konteks tempat penelitian diselenggarakan.

\section{HASIL PENELITIAN}

\section{Temuan Khusus}

\section{Pelaksanaan Pembelajaran membaca Al-qur'an}

Dalam pelaksanaan pembelajaran membaca Al-qur'an yang telah dilaksanakan di MTs Negeri Ujung Gurap Padangsidimpuan. Peneliti melakukan observasi dalam

11 Ibid, hlm. 329.

${ }^{12} \mathrm{Ibid}$, hlm. 329.

${ }^{13} \mathrm{Ibid}, \mathrm{hlm} .336$.

${ }^{14} \mathrm{Ibid}$, hlm. 338. 
pelaksanaan proses belajar mengajar membaca Al-qur'an, dimana proses belajar mengajar membaca Al-qur'an dilaksanakan selama 2 x 35 menit setiap pertemuan. Pembelajaran Baca Tulis Al-qur'an dilaksanakan dua kali dalam seminggu perkelasnya, dan setiap melaksanakan pembelajaran ilmu tajwid guru menggunakan langkah-langkah sebagai berikut: ${ }^{15}$

a. Sebelum Pelaksanaan Pembelajaran

Berdasarkan hasil wawancara peneliti dengan Bapak Mulia Nasution yang merupakan guru mengajar dalam membaca Al-qur'an bahwa Sebelum proses pembelajaran berlangsung; guru sudah membuat persiapan terhadap materi yang akan diajarkan, yang mana guru harus memperhatikan bahan pelajaran yang akan diajarkan dengan sebaik-baiknya, mengoreksi kesalahan-kesalahannya, menyusun sebaik mungkin sehingga mudah dipahami oleh murid sehingga dapat menumbuhkan minat mereka dalam belajar membaca Al-qur'an, dan guru hendaknya memikirkan metode yang cocok dalam menyampaikan pelajaran sehingga mudah pula diterima oleh siswa-siswi. ${ }^{16}$

Berdasarkan penjelasan diatas, peneliti dapat menyimpulkan bahwa sebelum proses belajar mengajar berlangsung guru harus mempersiapkan segala sesuatunya yang berkaitan degan apa yang akan diajarkan yaitu dengan memeriksa materi pelajaran yang akan dibahas dan mempersiapkan metode yang akan dipergunakan dalam mengajarkannya sehingga materi pelajaran tersebut mudah difahami.

b. Ketika Pelaksanaan Pembelajaran

Diantara upaya yang dilakukan guru dalam melaksanakan pembelajaran membaca Al-qur'an kepada siswa-siswi Kelas VII MTs Negeri Ujung Gurap Padangsidimpuan ketika proses belajar berlangsung adalah dengan memilih contoh ayat-ayat dan kata-kata yang sederhana dan mudah difahami.

\footnotetext{
${ }^{15}$ Obesevasi,, Pelaksanaan Pembelajaran Baca Tulis Al-Qur'an, di MTs Negeri Ujung Gurap, pada tanggal 27 Januari 2019.

${ }^{16}$ Sogir Nasution, Guru Baca Tulis Al-qur'an, Wawancara, Ruang Guru MTs Negeri Ujung Gurap, 29 Januari 2019.
} 
Sesuai dengan hasil pengamatan peneliti saat proses pembelajaran sedang berlangsung bahwa diantara upaya yang guru lakukan dalam mengajarkan membaca Al-qur'an adalah setiap belajar membaca Al-qur'an selalu megaitkannya dengan mencontohkan ayat-ayat pendek yang mudah difahami. ${ }^{17}$

c. Setelah Pelaksanaan Pembelajaran

Dari hasil pengamatan peneliti setelah pelaksanaan pembelajaran sudah selesai, guru membaca Al-qur'an memberikan evaluasi yakni menyuruh siswa-siswi untuk membaca Al-qur'an dengan menerapkan pelajaran yang sudah dipelajari.setelah selesai mengevaluasi yakni menerapkan pelajaran yang sudah dipelajari maka, guru mengajak siswa-siswi membaca do'a pelajaran, kemudian siswa-siswi menyalami guru-gurunya. ${ }^{18}$

Dari uraian diatas dapat disimpulkan bahwa pembelajaran membaca Alqur'an di MTs Negeri Ujung Gurap Padangsidimpuan telah diterapkan semaksimal mungkin, dengan memiliki dasar dan tujuan serta metode, tetapi penguasaan peserta didik terhadap membaca Al-qur'an masihkurang mampu, artinya aspek kemampuan mereka dalam meguasai pelajaran membaca Al-qur'an (BQ) belum memuaskan, hal ini sesuai dari hasil evaluasi yang dilakukan oleh guru-guru setelah selesai pembelajaran.

\section{Faktor-Faktor yang Mempengaruhi Kemampuan Belajar BQ}

Dalam kegiatan belajar mengajar membaca Al-qur'an terdapat dua faktor yang ikut menentukan keberhasilan siswa, yakni pengaturan proses belajar mengajar dan pengajaran itu sendiri.

Adapun faktpor-faktor yang mempengaruhi kemampuan belajar membaca Al-qur'an di MTs Negeri Ujung Gurap Padangsidimpuan. Namun garis besar faktor-faktor tersebut adalah faktor internal dan faktor eksternal. Faktor-faktor internal itu ialah mencakup minat, motivasi dan pemahaman siswa-siswi terhadap membaca Al-qur'an.

${ }^{17}$ Obesevasi, proses Pelaksanaan Pembelajaran Baca Tulis Al-Qur'an, di MTs Negeri Ujung Gurap, pada tanggal 29 Januari 2019.

${ }^{18}$ Obesevasi, setelah Pelaksanaan Pembelajaran Baca Tulis Al-Qur'an, di MTs Negeri Ujung Gurap, pada tanggal 29 Januari 2019. 
Adapun faktor-faktor eksternalnya ialah mencakup guru, bahan pelajaran, dan media pembelajaran yang berkaitan dengan pelajaran membaca Al-qur'an.

\section{a.Internal}

Faktor internal merupakan faktor-faktor yang mempengaruhi keberhasilan yang muncul dari dalam diri peserta didik. Faktor-faktor internal itu mencakup minat, motivasi, dan pemahaman peserta didik itu sendiri.

1) Minat

Salah satu faktor yang mempengaruhi prestasi belajar pada anak adalah minat belajar. Minat belajar yang tinggi akan mendukung berlangsungnya proses belajar mengajar membaca Alqur'an. Belajar dengan minat akan mendorong peserta didik belajar lebihbaik dari pada belajar tanpa minat. Minat itu timbul apabila peserta didik tertarik akan sesuatusesuai dengan kebutuhannya atau merasa bahwa sesuatu yang akan dipelajari dirasakan bermakna bagi dirinya. Hal ini sesuai dengan hasil awancara dengan Siti Kholijah salah satu peserta didik kelas VII MTs Negeri Ujung Gurap Padangsidimpuan menyatakan:

Pada saat berlangsung proses pebelajaran Baca Tulis Alqur'an, kami selalu mendengarkan penjelasan dari guru kami tentang apa yang disampaikan, dan kami tidak mau berbuat keributan saat proses pembelajaran berlagsung, kami juga menanyakan apa yang tidak kami mengerti tentang materi yang dijelaskan guru. $^{19}$

Namun setelah peneliti melaksanakan pengamatan langsung ternyata masih ada siswa-siswi yang suka bermain dan mengganggu temannya saat pembelajaran berlangsung.

2) Motivasi

Motivasi merupakan faktor yang sangat penting di dalam proses pembelajaran. Motivasi memberi semangat seorang pelajar dalam kegiatan proses pembelajaran, motivasi timbul dari dorongan yang asli atau perhatian

${ }^{19}$ Siti Kholijah, Siswa MTs Negeri Ujung Gurap, wawancara 30 Januari 2019. 
yang di inginkan. Guru bertanggung jawab melaksanakansystem pembelajaran agar berhasil dengan baik, keberhasilan ini tergantung pada upaya guru membangkitkan motivasi belajar anak. Hal ini sesuai dengan hasil wawancara dengan Khoiruddin yang merupakan siswa MTs Negeri Ujung Gurap Padangsidimpuan menyatakan:

Kami sering mengulang-ulang pelajaran yang sudah diajarkan guru dan selalu mengerjakan tugas pelajaran membaca membaca Al-qur'an yang diberikan guru, membentuk diskusi kecil dalam mengerjakan tugas yang diberikan guru sehingga kami mampu menerapkan membaca dan menulis Al-qur'an dengan baik. ${ }^{20}$ Setelah diamati, guru sudah berupaya memberikan motivasi dan semangat dengan menceritakan hikmah-hikmah dalam membaca Al-qur'an sementara, siswa-siswipun antusias mendengarkan motivasi tersebut sehingga sebahagian siswa-siswi rajin mengulang pelajaran dan mengerjakan tugastugas yan diberikan oleh guru

3) Pemahaman Murid

Hampir seluruh dari siswa-siswi kelas VII masih kurang paham dengan pelajaran yang disampaikan oleh guru, namun ada juga yang paham, hal ini terbukti setelah diadakan evaluasi di akhir pertemuan, baik yang berkenaan dengan membaca maupun dengan menulis. Hal ini sesuai dengan hasil wawancara peneliti dengan Fitri Yanti yang merupakan siswi MTs Negeri Ujung Gurap Padangsidimpuan menyatakan:

Kami terkadang masih kurang paham dengan apa yang disampaikan guru kami terutama dalam hal membaca dan menulis. ${ }^{21}$

Namun setelah peneliti mengamati, ternyata masih ada siswa-siswi yang kurang faham tentang pelajaran yang telah diajarkan oleh guru, hal ini terlihat dari hasil evaluasi yang dilakukan oleh guru.

\footnotetext{
${ }^{20}$ Khoiruddin, Siswa MTs Negeri Ujung Gurap, wawancara 30 Januari 2019.

${ }^{21}$ Fitri Yanti, Siswa MTs Negeri Ujung Gurap, wawancara 30 Januari 2019
} 


\section{b. Eksternal}

Faktor eksternal merupakan salah satu faktor yang sangat berpengaruh keberhasilan dalam pembelajaran. Faktor eksternal dalam pembelajaran ialah faktor keberhasilan yang muncul dari luar dari diri anak seperti guru, bahan panduan, dan media pembelajaran.

1) Guru

Dalam pembelajaran membaca Al-qur'an guru-guru berupaya untuk melakukan variasi dalam gaya mengaja, variasi metode mengajar dan penggunaan media pengajaran. Hal ini sesuai dengan hasil wawancara peneliti dengan Ibu Siti Horas yang merupakan salah satu tenaga pendidik di MTs Negeri Ujung Gurap Padangsidimpuan menyatakan:

Setiap pengajaran yang dilakukan, saya selalu berusaha melakukan variasi suara, pendekatan, pemberian waktu, kontak pandang, gerakan anggota badan, dan pindah posisi dalam melakukan pengajaran, begitu juga halnya dengan memilih metode, saya selalu berupaya untuk memilih metode yang tepat dalam mengajarkan membaca Al-qur'an sehingga siswa-siswi mudah mengerti dan memahami apa yang diajarkan, selain itu saya selalu memberikan materi yang mudah di peragakkan, dan diakhir pelajaran saya melakukan evaluasi pada iswa-siswi untuk mengetahui sejauh mana muridmurid itu mengerti tentang materi yang diajarkan. ${ }^{22}$

Ketika peneliti melakukan pengamatan ternyata guru-guru belum mampu melihat kondisi siswa-siswi, dan tak mampu memberikan metode yang menyenangkan bagi murid-murid. Hal ini dapat dilihat ketika adanya siswa-siswi yang tak mau serius belajar pada saat pembelajaran berlangsung.

2) Bahan Panduan

Rancangan bahan pelajaran yang diberikan guru pada pembelajaran tersusun secara logis dan sistematis. Hal ini sesuai dengan hasil wawancara

\footnotetext{
${ }^{22}$ Siti Horas, Guru Baca Tulis Al-qur’an Ujung Gurap, wawancara 30 Januari 2019.
} 
peneliti dengan Bapak Mudatua Siregar yang merupakan salah satu guru BQ di MTs Negeri Ujung Gurap Padangsidimpuan menyatakan:

Sebelum saya berangkat mengajar saya terlebih dahulu menyiapkan materi pelajaran yang ingin disampaikan dan memulai pelajaran dengan megulang kembali sedikit palajaran yang sebelumnya, kemudian meyuruh siswa-siswi untuk mempraktekkannya. Setelah itu saya menjelaskan pelajaran sesuai dengan materi yang sudah disiapkan dan diakhir pelajaran saya kembali menyuruh siswa-siswi untuk menerapkan materi yang dipelajari hari ini. ${ }^{23}$

Ketika peneliti melakukan observasi ternyata ada disiapkan RPP yang sejak awal sudah dipersiapkan supaya pembelajaran berlangsung dengan baik.

3) Media Pembelajaran

Media pembelajaran merupakan salah satu yang mendukung keberhasilan dalam proses pembelajaran. Media pembelajaran yang tersedia di MTs Negeri Ujung Gurap Padangsidimpuan cukup memadai, hal ini sesuai degan hasil wawancara peneliti dengan Bapak Kepala Sekolah Ahmad Rifa'i yang menyatakan:

Media pembelajaran yang tersedia dan yang sekaligus yang dipergunakan guru mengajarkan membaca Al-qur'an antara lain buku panduan BQ, buku pegangan siswa satu persiswa, papantulis, dan infokus untuk memudahkan menyampaikan materi pelajaran. ${ }^{24}$ Namun setelah diteliti, fasilitas yang tersedia sesuai dengan apa yang disampaikan oleh Bapak Kepala Sekolah MTs Negeri Ujung Gurap Padangsidimpuan.

\section{Kendala-Kendala yang Dihadapi Guru dalam Meningkatkan Kemampuan Belajar BQ}

Dalam proses pembelajaran membaca Al-qur'an yang dilaksanakan di MTs Negeri Ujung Gurap Padangsidimpuan, guru menemukan beberapa kendala. Adapun kendala-kendala yang ditemukan guru membaca Al-qur'an dalam proses membaca

\footnotetext{
${ }^{23}$ Mudatua, Guru Baca Tulis Al-qur'an Ujung Gurap, wawancara 30 Januari 2019

${ }^{24}$ Ahmad Rifa'i, wawancara Kepala Sekolah MTs Negeri Ujung Gurap, 30 Januari 2019.
} 
Al-qur'an sesuai dengan hasil wawancara peneliti bersama Ibu Dahlia Sitompul yang menyatakan kurangnya minat belajar siswa-siswi, sehingga sulit untuk mengerti dalam hal membaca dan menulis yang dilakukan ketika kegiatan belajar-mengajar sedang berlangsung dan ada juga anak yang tidak mengalami kemajuan. Hal ini didasarkan oleh kurangnya memahami cara-cara membaca Al-qur'an, dan juga ada rasa bosa dalam mengikuti pelajaran tersebut. ${ }^{25}$ Selain yang disebutkan diatas, kendala yang juga ditemui dalm pembelajaran Baca Tulis Al-qur'an adalah alokasi waktu.

\section{Solusi yang Dilakukan Guru Untuk Mengatasi Kendala dalam Pembelajaran BQ}

Solusi yang dilakukan guru dalam mengatasi kendala-kendala dalam proses belajar mengajar adalah sebagaimana yang dilakukan oleh guru membaca Al-qur'an dalam meningkatkan pengetahuan membaca Al-qur'an pada siswa-siswi.

Dalam pelaksanakan pembelajaran membaca Al-qur'an yang telah dilaksanakan di MTs Negeri Ujung Gurap Padangsidimpuan, Kecamatan Ujung Gurap Padangsidimpuan, peneliti mengadakan wawancara tentang solusi yang dilakukan guru dalam mengatasi kendala dalam pembelajaran membaca Al-qur'an. Solusi yang diberikan guru agat tujusan pembelajaran tercapai dengan efektif dan efisien sebagaimana hasil wawancara dengan Ibu Erlanna Panggabean yang merupakan salah satu guru BQ MTs Negeri Ujung Gurap Padangsidimpuan. ${ }^{26}$

\section{a. Pembukaan}

Setiap mulai pembelajaran gru mengawali dengan mengajak siswa-siswi berdo'a, kemudian memberikan apersepsi serta pertanyaan singkat. Upaya ini dilakukan agar siswa termotivasi untuk mengikuti pelajaran dengan serius.

b. Metode

Metode yang digunakan guru dalam mengajarkan pelajaran membaca Alqur'an adalah dengan menggunakan metode ceramah, iqra' yang digunakan guru untuk menjelaskan seluruh materi yang berkaitan dengan membaca dan menulis,

${ }^{25}$ Dahlia Sitomul, Guru Baca Tulis Al-qur'a, wawancara, MTs Negeri Ujung Gurap 30 Januari 2019.

${ }^{26}$ Erlanna Panggabean, Guru Baca Tulis Al-qur'a, wawancara, MTs Negeri Ujung Gurap, 30 Januari 2019. 
setelah itu langsung diterapkan dalam membaca Al-qur'an. Kemudian guru menggunakan metode hafalan, yakni anak-anak disuruh menghafal ayat-ayat pendek atau disebut juga dengan jz'amma.

c. Sumber Belajar

Dalam rangka membantu guru untuk mempermudah pemahaman anak akan materi yang diajarkan, maka media yan dipakai adalah papan tulis, infocus, sedangkan sumber belajarnya adalah guru dan buku yang berkaitan dengan membaca Al-qur'an

d. Evaluasi

Sebelum pertemuan diakhiri, guru melakukan kegiatan menyimpulkan pelajaran dan memberikan kesempatan untuk bertanya kepada anak-anak. Hal ini dilakukan sebagai upaya untuk mengetahui kebehasilan mengajar apakah anak mampu memahami pelajaran dengan baik atau tidak.

Tindak lanjut dari hasil evaluasi akan diketahui berhasil atau tidaknya pembelajaran yang telah berlangsung. Maka dari itu guru selalu melakukan program tindak lanjut berupa:mengulas materi pelajaran pada awalpertemuan dan melakukan tugas individu.

Selain melaksanakan apa yang ada dalam rencana pembelajaran hal ini juga dilakukan dalam pelaksanaan pembelajaran sesuai dengan hasil wawancara bersama Bapak Mudatua Siregar. ${ }^{27}$

a. Pertama-tama prosespembelajaran diawali dengan salam dari guru dan do'a pembukaan

b. Pembelajaran secaraklasikal dimulai dengan guru mereviuw pembelajaran yang telah lalu serta menambah materi baru. Kemudian dilanjutkan dengan menjelaskan materi pokok dengan cara membacakan contoh beulang-ulang, suara keras, jelas dan benar karena anak lebih suka mendengar, meniru daripada menyimak bacaan.

${ }^{27}$ Mudatua Siregar, Guru Baca Tulis Al-qur’an Ujung Gurap, wawancara 30 Januari 2019. 
c. Pembelajaran dilanjutkansecara individual, yakni siswa-siswi satu persatuuntuk disuruh membaca Al-qur'an dihadapan guru sesuai dengan tingkat kemampuan penguasaanmateri

d. Guru-guru memberikan nasehat-nasehat, pesan-pean atau pertanyaanpertanyaan sebelum pembelajaran berakhir apabila masih ada waktu

e. Pembelajaran ditutup dengan membaca do'a setelah selesai belajar.

\section{PENUTUP}

\section{Kesimpulan}

1. Pelaksanaan pembelajaran membaca Al-qur'an di MTs Negeri Ujung Gurap Padangsidimpuan adalah dilakukan dengan alokasi waktu 2 x 35 menit dan dua kali pertemuan dalam seminggu yang meliputi persiapan, pelaksanaan, dan penutup

2. Problematika yang dihadapi peserta didik adalah kurangnya minat, motivasi, dan pemahaman peserta didik

3. Adapun solusi yang dilakukan oleh guru dengan berusaha memberikan motivasi, memberi contoh-contoh yang sederhana dan mudah difahami, serta memanfaatkan sebaik mungkin fasilitas yang tersedia

\section{DAFTAR PUSTAKA}

Margareta E. Bell Gredler. Belajar dan membelajarkan,(Jakarta: Rajawali, 1991)

Tim PenyusunDepartemen Agama RI, Al-Qur'an danTerjemah (Bandung: Diponorogo, 2000)

Tim PenyusunDepartemen Agama RI, Al-Qur'an dan Terjemah (Bandung: Diponorogo, 2000)

Tim PenyusunDepartemen Agama RI, Al-Qur'an dan Terjemah (Bandung: Diponorogo, 2000)

Aunurrahman, Belajar dan Pembelajaran, Bandung: Alfabeta, 2012.

S Sudjana, dan Djuju, Metode dan Teknik Pembelajaran Partisipatif, Bandung: Falah Production, 2001.

E.Mulyasa, Kurikulum Berbasis Kompetensi, Bandung: Remaja Rosdakarya Offset, 2003.

Ahamad ali Ash-Shabuuni, Attibyan fii ulumil Qur'an 
Departemen Pendidikan Dan Kebudayaan, Kamus Besar Bahasa Indonesia, Jakarta: Balai Pustka, 1989.

Hernowo, Quantum writing: cara cepat nan bermanfaat untuk merangsang munculnyapotensi menulis, (Bandung:Mizan Learning Center,2003),

K.H. Dahlan Salim Zarkasyi, Empat Langkah Pendirian TKQ/TPQ Metode Qiro'ati,(Semarang: Yayasan Pendidikan Al-Qur'an Roudhotul Mujahidin,1996)

Moleong, Lexy J, Metodologi Penelitian Kualitatif, Bandung: Rosda Karya, 2000.

Suhardi, Motodologi Penelitian Pendidikan Kompetensi dan Praktiknya, Jakarta: PT. Bumi Aksara, 2003.

Mardalis, Metode Penelitian Suatu Pendekatan Proposal, Jakarta: Bumi Aksara, 1995.

Sukardi, Metode Pendidikan Kompetensi dan Praktiknya, Jakarta: Bumi Aksara, 2013.

Ruslan, Rosady, Metode Penelitian, Jakarta: PT. Raja Grafindo Persada, 2003.

Tim Penyusun Departemen Agama RI, Al-Qur'an dan Terjemah, Bandung: Jumanatul Ali-ART, 2005. 